\title{
Antibiotic Susceptibility Pattern of Gram-negative Isolates of Lower Respiratory Tract Infection
}

\author{
Rakshya Nepal, ${ }^{1}$ Basudha Shrestha, ${ }^{2}$ Deepak Man Joshi, ${ }^{3}$ Rajesh Dhoj Joshi, ${ }^{3}$ Sanjit Shrestha, ${ }^{2}$ Anjana Singh ${ }^{1}$ \\ ${ }^{1}$ Central Department of Microbiology, Tribhuvan University, Kritipur, Kathmandu, Nepal, ${ }^{2}$ Department of \\ Microbiology, ${ }^{3}$ Department of Medicine, phect-NEPAL/ Kathmandu Model Hospital, Kathmandu, Nepal.
}

\section{ABSTRACT}

Background: Lower respiratory tract infection is a common cause of morbidity and mortality worldwide. A cross-
sectional study was carried out with an objective to study the antibiogram of Gram-negative isolates of patients with
lower respiratory tract infection visiting Kathmandu Model Hospital.
Methods: A total of 274 specimens including sputum, endotracheal aspirates, suction tips were cultured as per standard
microbiological technique. Antibiotic susceptibility and detection of Extended-spectrum beta- lactamases (ESBLs) were
performed following Clinical Laboratory Standard Institute (CLSI 2014) guidelines.
Results: Respiratory pathogens were recovered from $24.6 \%(\mathrm{n}=65)$ cases. Klebsiella pneumoniae (40\%) was the
commonest isolates. The highest prevalence of multidrug-resistance $(69.23 \%$ ) was observed in Acinetobacter calcoaceticus
baumannii complex. Extended-spectrum beta- lactamases were detected in Escherichia coli (n=4), Klebsiella pneumoniae
(n=4) and Acinetobacter calcoaceticus baumannii complex (n=1).
Conclusions: High prevalence of multidrug-resistance and extended- spectrum beta- lactamase producers were
observed in respiratory isolates. For effective management of lower respiratory tract infections, an ultimate and detailed
microbiological diagnosis and susceptibility testing is required.
Keywords: Extended -spectrum $\beta$-lactamase; multidrug-resistance.

\section{INTRODUCTION}

Lower respiratory tract infection (LRTI) is considered as one of the major public health problems and a leading cause of morbidity and mortality in many developing countries. ${ }^{1-3}$ It is a global problem accounting for over 50 million deaths each year and occurs in both community and health care settings. ${ }^{4}$ In developing countries, the situation is more complicated, and management is often difficult due to the problem associated with the identification of the etiological agents and the administration of an appropriate treatment in cases requiring antibiotic therapy. ${ }^{5} \mathrm{Gram}$-positive bacteria such as, Staphylococcus aureus, Streptococcus pneumoniae and Gram-negative bacteria such as Haemophilus influenzae, Pseudomonas spp, Acinetobacter spp., Klebsiella spp. have been recovered from LRTIs. ${ }^{6}$ This study was conducted with the aim of studying the Gramnegative etiological agents causing LRTI in patients of all age groups and their antibiogram with special interest to MDR in Kathmandu Model Hospital.

\section{METHODS}

This was a hospital based cross-sectional study which was conducted at Kathmandu Model Hospital, Kathmandu from the month of January 2016 to June 2016. A total of 274 specimens from the patients of suspected lower respiratory tract infection were included in the study. Lower respiratory tract (LRT) representing specimens, viz., sputum, endotracheal (ET) secretion and bronchial washings received for culture and sensitivity which met the criteria as recommended by American Society for Microbiology (ASM) were included in the study. ${ }^{7}$

The digested samples were cultured on Chocolate agar (CHA), 5\% Sheep Blood agar (BA) and MacConkey agar (MA) plates. The $\mathrm{CHA}$ and BA plates were incubated in $\mathrm{CO} 2$ incubator $\left(10 \% \mathrm{CO}_{2}\right)$ at $37^{\circ} \mathrm{C}$ for 24 hours while $\mathrm{MA}$ plates were incubated at $37^{\circ} \mathrm{C}$ for 24 hours in aerobic atmosphere.

All the bacteria were isolated and identified using morphological, microscopy and biochemical tests following standard procedures. ${ }^{7}$

All the respiratory isolates were tested for antibiotic susceptibility by modified Kirby Bauer disc diffusion method in compliance with CLSI 2014 guidelines on Mueller Hinton agar plates using amoxicillin (10 ug),

Correspondence: Dr Basudha Shrestha, Department of Microbiology, phectNEPAL/ Kathmandu Model Hospital , Exhibition Road, Kathmandu, Nepal. Email: basudha111@hotmail.com, Phone: +9779851030594. 
Antibiotic Susceptibility Pattern of Gram-negative Isolates of Lower Respiratory Tract Infection

cephotaxime ( $30 \mathrm{ug})$, ceftriaxone (30 ug), ciprofloxacin (5 ug), ofloxacin (5 ug), chloramphenicol (30 ug), cotrimoxazole (25 ug), chloramphenicol (30 ug), gentamycin (10 ug ) and azithromycin (30 ug). Isolates were labeled as MDR if they were resistant to at least two classes of first line agents. The confirmation of ESBL was done by combination disc method in which ceftazidime (CAZ) and cefotaxime (CTX) alone and in combination with clavulanic acid (CA) $(10 \mu \mathrm{g})$ was used. An increased zone of inhibition (ZOI) of $\geq 5 \mathrm{~mm}$ for either antimicrobial agent in combination with CA versus its zone when tested alone confirmed ESBL. ${ }^{8}$

\section{RESULTS}

A total of 274 specimens from patients with LRT were processed according to the standard microbiological methods. Specimens processed in this study include Sputum $(n=264)$, ET secretion $(n=6)$ and Suction tip $(n=4)$. Among 264 sputum specimens, 254 were further processed while the remaining 10 specimens were rejected as they were found to be oral contamination. Among the total processed specimen $(\mathrm{N}=264), 65$ (24.6\%) showed significant growth (Table 1$)$.

\begin{tabular}{|c|c|c|}
\hline Specimen & $\begin{array}{r}\text { Significant } \\
\text { growth }\end{array}$ & No growth \\
\hline & No. $\%$ & No. $\%$ \\
\hline Sputum(n=254) & $56(22.04)$ & $198(77.95)$ \\
\hline $\begin{array}{l}\text { Endotracheal secretion } \\
(n=6)\end{array}$ & $5(83.33)$ & $1(16.66)$ \\
\hline Suction Tip $(n=4)$ & $4(100)$ & $0(0)$ \\
\hline
\end{tabular}

Out of 65 microbial growth, there was polymicrobial growth (growth of more than one microbe) in 10 specimens $(15.36 \%)$ while monomicrobial growth was seen in $55(84.6 \%)$. Most of the isolates $(63.07 \%)$ were obtained from samples of in-patients and $36.92 \%$ of isolates were from out-patients.

Eight different bacteria were isolated. Among the 75 bacteria isolates, K. pneumoniae ( $n=30,40.00 \%)$ was found most predominant organism followed by Pseudomonas spp $(\mathrm{n}=16,21.33 \%)$, Acinetobacter spp $(\mathrm{n}=13,17.33 \%)$, E. coli $(\mathrm{n}=11,14.66 \%)$, C. freundii $(\mathrm{n}=2$, $2.66 \%)$, C. koseri $(n=1,1.33 \%)$, Enterobacter $\operatorname{spp}(n=1$, $1.33 \%)$ and $K$. oxytoca $(n=1,1.33 \%)$. Distribution of ESBL and MBL in MDR $E$.coli is shown in Table 2.

$\begin{array}{lrr}\text { Table 2. Distribution of microbial isolates from LRTI } \\ \text { (N=75). } \\ \text { Organism } & \begin{array}{r}\text { Number of } \\ \text { cases }(\mathrm{n})\end{array} & \% \text { amongst total } \\ & \end{array}$

\begin{tabular}{lrr}
\hline K. pneumonia & 30 & 40.00 \\
\hline P. aeruginosa & 16 & 21.33 \\
\hline E. coli & 11 & 14.66 \\
\hline ACBC & 13 & 17.33 \\
\hline C. freundii & 2 & 2.66 \\
\hline C. koseri & 1 & 1.33 \\
\hline K. oxytoca & 1 & 1.33 \\
\hline Enterobacter spp & 1 & 1.33 \\
\hline${ }^{* *}$ Acinetobacter calcoaceticus baumannii complex & \\
\hline
\end{tabular}

K. pneumoniae showed $50 \%(15 / 30)$ sensitivity toward gentamicin, $46.7 \%(14 / 30)$ sensitivity toward ciprofloxacin, $36.7 \%(11 / 30)$ toward cefixime. Antibiotic least effective were cotrimoxazole, cefotaxime $33.3 \%$ $(10 / 30)$ each and amoxicillin clavulanic acid 3.3\% (1/30). K. pneumoniae showed $100 \%(0 / 30)$ resistant toward amoxycillin as shown in the Table 3.

\section{Table 3. Antibiogram of $K$. pneumoniae $(\mathrm{N}=30)$.}

\begin{tabular}{|lrrr|}
\hline Antibiotics & \multicolumn{3}{c}{ Antibiotic susceptibility pattern } \\
& Sensitive & Resistant & Sensitivity\% \\
\hline Amoxycillin & 0 & 30 & $0 \%$ \\
\hline $\begin{array}{l}\text { Amoxycillin- } \\
\text { clavulanic acid }\end{array}$ & 1 & 29 & $3.3 \%$ \\
\hline Cotrimoxazole & 10 & 20 & $33.3 \%$ \\
\hline Cefixime & 11 & 19 & $36.7 \%$ \\
\hline Cefotaxime & 10 & 20 & $33.33 \%$ \\
\hline Ciprofloxacin & 14 & 16 & $46.7 \%$ \\
\hline Gentamicin & 15 & 15 & $50 \%$ \\
\hline Azithromycin & 11 & 17 & $43.3 \%$ \\
\hline
\end{tabular}

E. coli are more susceptible to gentamicin, cotrimoxazole and ciprofloxacin $36.4 \%(4 / 11)$ equally followed by cefixime, cefotaxime $27.3 \%(3 / 11)$ and amoxycillin, amoxycillin-clavulanic acid and azithromycin 18.2\% (2/11). (Table 4)

Acinetobacter calcoaceticus baumannii complex showed more susceptibility toward the cotrimoxazole and gentamicin $30.8 \%$ (4/13) followed by azithromycin $23.0 \%$ (3/13); whereas amoxycillin-clavulanic acid, cefotaxime, and ciprofloxacin demonstrated $15.4 \%(2 / 13)$ sensitivity each. Amoxycillin and cefixime are least susceptible with $7.7 \%(1 / 13)$ senstivity each. (Table 5)

Table 4. Antibiogram of $E$. coli $(\mathrm{N}=11)$.
\begin{tabular}{crrr} 
Antibiotics & Antibiotic & susceptibility pattern \\
& Sensitive & Resistant & Sensitivity\% \\
\hline Amoxycillin & 2 & 9 & $18.2 \%$
\end{tabular}


Antibiotic Susceptibility Pattern of Gram-negative Isolates of Lower Respiratory Tract Infection

\begin{tabular}{|c|c|c|c|}
\hline $\begin{array}{l}\text { Amoxycillin } \\
\text {-clavulanic } \\
\text { acid }\end{array}$ & 2 & 9 & $18.2 \%$ \\
\hline Cotrimoxazole & 4 & 7 & $36.4 \%$ \\
\hline Cefixime & 3 & 8 & $27.3 \%$ \\
\hline Cefotaxime & 3 & 8 & $27.3 \%$ \\
\hline Ciprofloxacin & 4 & 7 & $36.4 \%$ \\
\hline Gentamicin & 4 & 7 & $36.4 \%$ \\
\hline Azithromycin & 2 & 9 & $18.2 \%$ \\
\hline
\end{tabular}

Pseudomonas aeruginosa showed $93.7 \% \quad(15 / 16)$ sensitivity toward amikacin followed by gentamicin $87.5 \%(14 / 16)$, ofloxacin $75 \%(12 / 16)$, piperacillintazobactam $81.25 \%(13 / 16)$, ciprofloxacin $75 \%(12 / 16)$ and levofloxacin $75 \%(14 / 16)$. Ceftazidime $37.5 \%(6 / 16)$ and piperacillin $25 \%(4 / 16)$ were the least effective to Pseudomonas aeruginosa. (Table 6)

\begin{tabular}{lrrr}
\hline $\begin{array}{l}\text { Table 5. Antibiogram of Acinetobacter } \\
\text { calcoaceticus baumannii complex }(\mathrm{N}=13) .\end{array}$ \\
$\begin{array}{l}\text { Name of } \\
\text { antibiotic used }\end{array}$ & \multicolumn{4}{l}{ Antibiotic susceptibility pattern } \\
& Sensitive & Resistant & Sensitivity\% \\
\hline $\begin{array}{l}\text { Amoxycillin } \\
\text { Amoxycillin }\end{array}$ & 1 & 12 & $7.7 \%$ \\
-clavulanic & 2 & 11 & $15.4 \%$ \\
acid & & & \\
Cotrimoxazole & 4 & 9 & $30.8 \%$ \\
\hline Cefixime & 1 & 12 & $7.69 \%$ \\
\hline Cefotaxime & 2 & 11 & $15.4 \%$ \\
\hline Ciprofloxacin & 2 & 11 & $15.4 \%$ \\
\hline Gentamicin & 4 & 9 & $30.8 \%$ \\
\hline Azithromycin & 3 & 10 & $23.0 \%$ \\
\hline
\end{tabular}

\begin{tabular}{|c|c|c|c|}
\hline \multirow[t]{2}{*}{ Antibiotics } & \multicolumn{3}{|c|}{ Antibiotic susceptibility pattern } \\
\hline & Sensitive & Resistant & Sensitivity\% \\
\hline Piperacillin & 4 & 12 & $25 \%$ \\
\hline Ceftazidime & 6 & 10 & $37.5 \%$ \\
\hline Ciprofloxacin & 12 & 4 & $75 \%$ \\
\hline Gentamicin & 14 & 2 & $87.5 \%$ \\
\hline Cefipime & 11 & 5 & $68.75 \%$ \\
\hline \multirow{3}{*}{$\begin{array}{l}\text { Amikacin } \\
\text { Piperacillin- } \\
\text { tazobactem } \\
\text { Ofloxacin }\end{array}$} & 14 & 1 & $93.75 \%$ \\
\hline & 13 & 3 & $81.25 \%$ \\
\hline & 12 & 4 & $75.0 \%$ \\
\hline Levofloxacin & 11 & 4 & $68.75 \%$ \\
\hline
\end{tabular}

The data showed that Acinetobacter calcoaceticus baumannii complex $69.23 \%$ (9/13), E. coli $54.54 \%$ (6/11), K. pneumoniae 50\% (15/30) and Pseudomonas aeruginosa $12.5 \%(2 / 16)$ were found to be MDR. (Table 7$)$

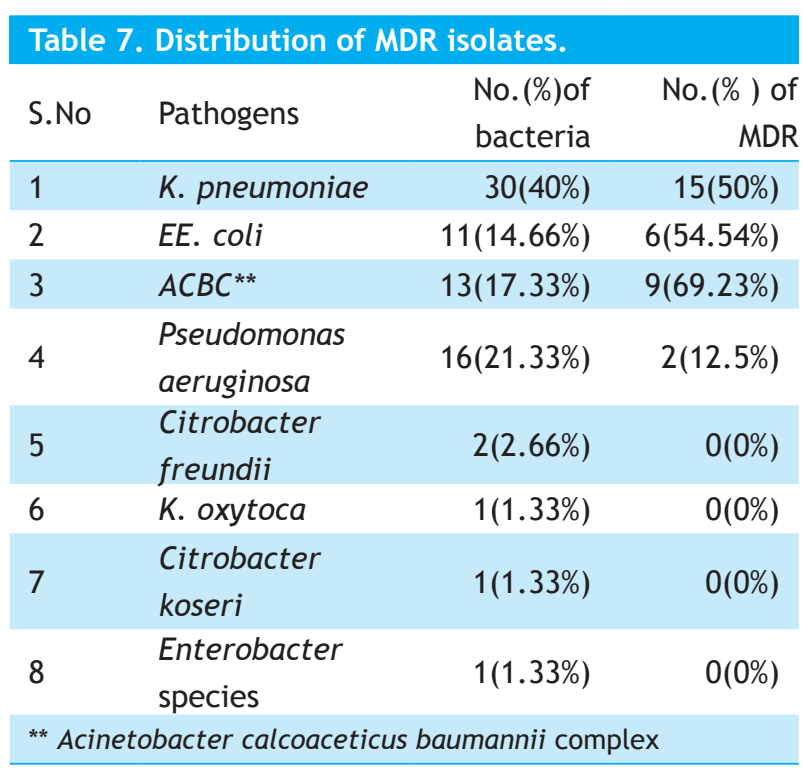

Among 6 MDR isolates of $E$. coli, ESBL was detected in $4(66.67 \%)$, among 15 MDR isolates of $K$. pneumoniae, ESBL was detected in 4 (26.66\%) and of 9 MDR isolates of Acinetobacter calcoaceticus baumannii complex, ESBL was detected in $1(11.11 \%)$. All ESBL producing isolates are MDR. The result is shown in Table 8 .

\begin{tabular}{|c|c|c|c|c|}
\hline SN & Pathogens & $\begin{array}{c}\text { Total } \\
\text { Isolates } \\
\text { No. }\end{array}$ & $\begin{array}{c}\text { MDR } \\
\text { No. }\end{array}$ & $\begin{array}{r}\text { ESBL } \\
\text { Isolates } \\
\text { No (\%) }\end{array}$ \\
\hline 1 & $\begin{array}{l}\text { K } \\
\text { pneumoniae }\end{array}$ & 30 & 15 & $4(26.66 \%)$ \\
\hline 2 & E. coli & 11 & 6 & $4(66.67 \%)$ \\
\hline 3 & $A C B C^{* *}$ & 13 & 9 & $1(11.11 \%)$ \\
\hline 4 & $\begin{array}{l}P \\
\text { aeruginosa }\end{array}$ & 16 & 2 & $0(0 \%)$ \\
\hline 5 & Total & 70 & 32 & $9(28.125 \%)$ \\
\hline
\end{tabular}

** Acinetobacter calcoaceticus baumannii complex

\section{DISCUSSION}

This study was undertaken to find out the bacteriological profile and the sensitivity pattern of the isolates. Growth of pathogens was obtained in 65/264 (24.62\%). Culture positivity depends on the nature of specimen, transportation time and the number of organism present in the sample. In comparison to other studies, ${ }^{9,10}$ the yield of sputum culture in this study is low (24.66\%) but similar to studies done by Egbe et al and Ahmed et al. ${ }^{11,12}$ The lower isolation of pathogens in the present study might be attributed to several potential factors in comparison to other studies. The natural infection in patients may have already been changed by the use of antibiotics by healthcare providers at different level of care before patients reach to hospitals. Major cause of culture negativity in lower respiratory tract infections 
might be the prior use of antibiotics. ${ }^{13}$ Viruses like adenovirus, respiratory syncytial virus, parainfluenza virus and rhino virus, which are significant contributors of LRTI, were not looked for in our study due to limitation of resources. Likewise, common pulmonary pathogens such as Mycobacterium tuberculosis, Mycoplasma, Chlamydia, Pneumocystis, Fungi, Legionella, and anaerobes could not be cultured by routine methods.

Eight different bacteria were isolated, giving the growth rate of $24.62 \%$. The bacteria isolated from the samples included K. pneumonia (40\%), P. aeruginosa (21.33\%), $E$. coli $(14.66 \%)$, Acinetobacter calcoaceticus baumannii complex (17.33\%), C. freundii $(2.66 \%)$, K. oxytoca (1.33\%), C. koseri (1.33\%) and Enterobacter spp (1.33\%). Pathogens were obtained from $63.07 \%$ of samples in case of in-patients and $36.92 \%$ in out-patients. K. pneumoniae (40.82\%) was the most common pathogen isolated from in-patients, whereas P. aeruginosa $(26.54 \%)$ was the second predominant organism in hospitalized patients. This study was very much related to the similar study carried by Ahmed et al. ${ }^{12}$ The isolation of $K$. pneumoniae as predominant organism also agrees with other studies carried out elsewhere. ${ }^{14,15}$

The increasing resistance to antibiotics by respiratory pathogens has complicated the use of empirical treatment with traditional agents and a definitive bacteriological diagnosis and susceptibility testing would, therefore, be required for effective management of LRTI.

Quinolones were found to be the most effective antibiotic against the Gram-negative bacteria in this study; most of the isolates were sensitive to the quinolones (ciprofloxacin, ofloxacin), but resistant to amoxycillin, cotrimoxazole and cefotaxime. The data showed that Acinetobacter calcoaceticus baumannii complex (69.23\%), E. coli (54.54\%), K. pneumoniae (50\%) and $P$. aeruginosa $(12.5 \%)$ were frequent MDR isolates. The pattern of antibiotic resistance recorded in this study among $P$. aeruginosa, K. pneumoniae and $E$. coli isolates is correlated well with the results obtained from Kumari et al. ${ }^{16}$ and Gauchan et al. ${ }^{17}$ The decreased susceptibility of Gram-negative isolates towards third generation cephalosporins $(5-40 \%)$ could be attributed to ESBL production. ESBL production was the most common among E. coli (36.36\%) followed by Klebsiella pneumoniae (13.33\%). But in a study by Pokhrel et al , K. pneumoniae $(65 \%)$ and E. coli $(70 \%)$ were ESBL producers. ${ }^{18}$ This is probably because their study was based on infections in intensive care unit, whereas the present study included both community acquired and nosocomial infections. The importance of ESBL producing strains lies in the fact that they are difficult to treat because they carry plasmids that confer resistance to many other antibiotics.

\section{CONCLUSIONS}

High prevalence of multidrug-resistance and extendedspectrum beta- lactamase producers were observed in respiratory isolates. For effective management of lower respiratory tract infections, an ultimate and detailed microbiological diagnosis and susceptibility testing is required. Thus, longitudinal surveillance program, institution of infection control practices and rational use of antibiotics are highly recommended to reduce the infection rate and limit the spread of resistance.

\section{ACKNOWLEDGEMENTS}

The authors are thankful to Kathmandu Model Hospital, Kathmandu, Nepal for providing the platform to perform this study. The authors would also like to thank all participants of this study and the laboratory staffs for their help during the study.

\section{REFERENCES}

1. Prajapati B, Talsania N, Sonaliya KN. A study on prevalence of acute respiratory Tract infections (ARI) in under five children in Urban and rural communities of Ahmedabad District, Gujarat. Nat J Com Med. 2011; 2:255-59.

2. Jacobs E, Dalhoff A, Korfmann G. Susceptibility patterns of bacterial isolates from hospitalised patients with respiratory tract infections. Int J Antimicrob Agents. 2009;33:52-7.[PubMed]

3. Sharma R, Sharma CL, Kapoor B. Antibacterial resistance: current problems and possible solutions. Ind J Med Sci. 2005;59:120-29. [PubMed]

4. Zafar A, Hussain Z, Lomama E, Sibiie S, Irfan S, Khan E. Antibiotic susceptibility of pathogens isolated from patients with community-acquired respiratory tract infections in Pakistan- the active study. J Ayub Med Coll Abbottabad.2008;20:7-9.[PubMed]

5. Murray CJ, Lopez L. Mortality by cause for eight regions of the world: Global burden of disease. Lancet.1997;349:1269-76.[Full Text]

6. Ozyilmaz E, Akan OA, Gulhan M. Major bacteria of community-acquired respiratory tract infections in Turkey. Jpn J Infect Dis. 2005;58:50-2.[Full Text]

7. Isenberg HD. Clinical Microbiology Procedures Handbook. 2nd ed. Washington, D.C: ASM Press 2004.

8. Clinical Laboratory Standard Institute: Performance standards for antimicrobial susceptibility testing; Twenty- 
second informational supplement document. Wayne, PA: CLSI.2012;M100-S20.

9. Khan S, Singh P, Ansari M, Gurung K . Bacterial etiological agents causing lower respiratory tract infections in the western part of Nepal. Ibnosina J Med.2014; 6: 3-8. [Full Text]

10. Imani R, Rouhi H, Ganji F. Prevalence of antibiotic resistance among bacteria isolates of lower respiratory tract infection in COPD Shahrekord, Iran. Pak J Med Sci. 2005;23:438-40.[Full Text]

11. Egbe CA, Ndiokwere C, Omeregie R. Microbiology of lower respiratory tract infections in Benin city, Nigeria. J Med Sci. 2011;18:27-31.[Full Text]

12. Ahmed SM, Jakribettee RK, Meletath SK, Arya B, Shakir VP. Lower respiratory tract infections (LRTIs): an insight into the prevalence and antibiogram of the Gram negative respiratory bacterial agents. J Clin Diag Res. 2013;7:25356.

13. Bartlett JG, Dowell SF, Mandel L.A., File TM, Musher DM Jr, Fine MJ . Practice guidelines for the management of community-acquired pneumoniae in adults. Clin Infect Dis. 2000;31:347-382.[Full Text]

14. Okesola AO, Oni AA. Antimicrobial resistance among common bacterial pathogens in South Western Nigeria. American-Eurasian J Environ Sci. 2009;5:327-30.[Full Text]

15. Tripathi C, Dhote K. Lower respiratory tract infections: current etiological trend and antibiogram. J Pharma Biomed Sci. 2014;4:249-55.

16. Kumari HB, Nagarathna S, Chandramuki A. Antimicrobial resistance pattern among aerobic Gram-negative bacilli of lower respiratory tract illness in the community. Thorax.2007;56:109-14.[PubMed]

17. Gauchan P, Lekhak B, Sherchand JB. The Prevalence of lower respiratory tract infection in adults visiting Tribhuvan University Teaching Hospital. J Inst Med. 2006;28(2):10 14.[Full Text]

18. Vishwanath S, Chawla, K, Gopinathan A. Multidrug resistant Gram-negative bacilli in lower respiratory tract infections. Iranian J Microbiol. 2013; 5(4): 323-27.[Full Text] 